mag. Nadja

Dobnik

Ekonomska fakul-

teta v Ljubljani

\section{Pomen izobraževanja na daljavo za gospodarstvo}

$\mathbf{P}_{0}$ je zadnjem desetletju izredno razširil in populariziral. Na to, kaj je izobraževanje na daljavo in kakšno vlogo ima kot ena od oblik izobraževanja odraslih, je veliko različnih pogledov. Didaktika izobraževanja na daljavo se je $\mathrm{z}$ razvojem novih tehnologij naglo spreminjala in odkrivanje didaktične funkcije računalnika odpira nove razsežnosti ter možnosti za posredovanje znanja in informacij. Obenem pa je izobraževanje na daljavo iz domene strokovnjakov za izobraževanje odraslih vse bolj prehajalo pod okrilje strokovnjakov za nove tehnologije in informatikov. O tem nesporno pričajo tudi konference združenj za izobraževanje na daljavo (EDEN, ICDE), na katerih je med udeleženci delež informatikov in računalničarjev iz leta v leto večji, s tem pa tudi število prispevkov, ki so povsem tehnične narave.

V Sloveniji so se prizadevanja za širšo uveljavitev izobraževanja na daljavo pojavila prav v času uveljavljanja interneta in iskanja novih možnosti za izobraževanje na daljavo po internetu. Žal je to tudi negativno vplivalo na mnenje o tem, kaj je izobraževanje na daljavo. Pri nas je zelo razširjeno mnenje, da je izobraže-

Sodelovanje andragogov $z$ informatiki je pri razvijanju računalniško podprtega izobraževanja na daljavo nujno, saj so brezhibno delujoče računalniške povezave pogoj za uspešen potek izobraževanja. Vendar računalniška tehnologija še vedno ostaja le medij oziroma orodje, s katerim se prenašajo izobraževalne vsebine. vanje na daljavo izobraževanje prek računalnika in interneta. Mnogi pa so tudi prepričani, da izobraževanja na daljavo pri nas ne potrebujemo preprosto zato, ker je Slovenija majhna in nam tako kratkih razdalj ni treba premagovati s posebno obliko študija. Vsekakor lahko z gotovostjo trdimo, da se pri nas ne zavedamo (ali nočemo zavedati) pomena in prednosti, ki ga ima izobraževanje na daljavo.

Izobraževanje na daljavo ima v zahodnoevropskih državah dolgo tradicijo in prepoznavno mesto $\mathrm{v}$ izobraževalnem sistemu. Tradicionalno bi ga lahko na kratko opredelili kot obliko izobraževanja, pri kateri je izobraževalni proces organiziran na način, ki posamezniku omogoča čim kakovostnejše samostojno izobraževanje. Snovi ne posreduje učitelj na predavanjih, ampak je zajeta $\mathrm{V}$ študijskem gradivu. S tem se težišče prenosa znanja prestavi $\mathrm{z}$ učitelja $\mathrm{v}$ razredu na posebej pripravljeno gradivo (to so lahko učbeni$\mathrm{ki}$, vadnice, video in avdio kasete, CDROM-i, računalniški paketi, baze podatkov ipd.), ki udeležencu omogoča, da vso potrebno snov, podatke ali informacije o določenem področju predela sam. Študent je praviloma vezan na organizacijo in razporeditev obveznosti, ki jih predpiše izobraževalna organizacija, vendar mu študijsko gradivo omogoča, da študira takrat in tam, kadar in kjer mu najbolj ustreza glede na obveznosti, ki jih ima v poklicnem in zasebnem življenju. Da izobraževanje ne poteka $\mathrm{v}$ popolni osami in brez živega stika s izobraževalno organizacijo, je študentu v oporo mentor ali svetovalec, na katerega se študent lahko obr- 
ne, ko naleti na težave pri razumevanju snovi ali potrebuje povratne informacije.

Bistven poudarek pri izobraževanju na daljavo torej ni v tem, kateri medij bo uporabljen kot orodje za prenos izobraževalnih vsebin (na primer učbenik, računalnik, CD-ROM ali internet), bistveno je vprašanje samih vsebin, ki morajo biti študentu posredovane tako, da jih osvoji enako kakovostno, kot če bi mu jih posredoval učitelj $\mathrm{v}$ neposrednem stiku. S strani izvajalca izobraževanja se težišče priprave takega izobraževalnega procesa skoraj $\mathrm{v}$ celoti prenese $\mathrm{v}$ fazo programiranja vsebin in načrtovanja, $v$ kateri je treba narediti zaokrožen koncept vsebin in napisati oziroma pripraviti gradivo, pri klasičnem, neposrednem (face-to-face) izobraževanju pa je poudarek na delu učitelja v skupini. V obeh primerih pa ostaja ključno vprašanje vsebin, torej vprašanje, kaj se bodo udeleženci izobraževanja učili in naučili, sama oblika in izvedba oziroma vprašanje, kako se bodo učili (predavanja, tečaj, vodeno samoizobraževanje ali individualni učni projekt), pa sta lahko odvisni od konkretnih okoliščin in možnosti.

Razlog za to, da izobraževanje na daljavo poteka večinoma na ravni postsekundarnega izobraževanja (po srednji šoli), je povezan z

Izvedba izobraževanja na daljavo zahteva razmeroma velike predpriprave in investicije, zato se je tudi v praksi izkazalo za najprimernejše takrat, kadar je treba v izobraževanje vključiti veliko število študentov. V razvitih državah so najpomembnejša ciljna populacija izobraževanja na daljavo odrasli, vpisani v programe postsekundarnega študija, torej na ravni izrednega dodiplomskega in podiplomskega študija. V večini držav se izredni študij izvaja (le) kot študij na daljavo, študenti se $z$ mentorjem ali predavateljem sreěujejo le občasno ali imajo stike z njim prek medijev (telefon, elektronska pošta). razvitostjo učnih navad in spretnosti, potrebnih za samostojen študij pisnih virov. Praviloma šele solidna srednja šola zagotavlja primerno razvite učne navade in sposobnost samostojnega dela s pisnimi viri (bralno razumevanje, interpretacija besedil, sposobnost sintetiziranja prebranega, pisanje zapiskov ipd.). Zato je za raven osnovne in srednje šole izobraževanje na daljavo manj primerno in se izvaja predvsem pri otrocih in mladostnikih s posebnimi potrebami, ki se zaradi bolezni, invalidnosti ali iz drugih razlogov ne morejo udeleževati pouka.

Ciljna populacija izobraževa-

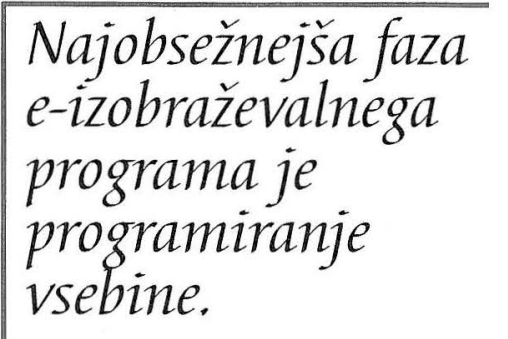
nja na daljavo so predvsem odrasli, ki imajo zaradi poklica in drugih obveznosti zelo omejen čas za učenje in se težko redno udeležujejo predavanj ter skupinskih srečanj. Prav s tega vidika ima lahko izobraževanje na daljavo pomembno vlogo za različne vrste izobraževanja v gospodarstvu, bodisi pri krajših oblikah strokovnega izpopolnjevanja bodisi pri daljših oblikah študija za pridobitev višje stopnje izobrazbe.

\section{IZOBRAŽEVANJE NA DALJAVO ZA POTREBE GOSPODARSTVA}

Potrebe zaposlenih v gospodarstvu in gospodarstva samega po novem znanju, spretnostih in sposobnostih se pojavljajo $\mathrm{z}$ veliko dinamiko in na različnih ravneh. Gre za potrebe podjetij in njihovih razvojnih ciljev in tudi za potrebe zaposlenih, povezane $\mathrm{z}$ opravljanjem poklica in z njihovo lastno vizijo kariere ter osebne rasti. Področje izobraževalnih potreb je v gospodarstvu kompleksna pahljača, v kateri se združujejo različni in celo nasprotni interesi. Od tega, koliko in kako bodo te potrebe in ti interesi zadovoljeni, je odvisen osebni in poklicni razvoj posameznega zaposlenega, pa tudi usoda podjetja in s tem blaginja skupnosti, kraja ali regije. 
Izobraževanje $v$ gospodarstvu je $z$ vidika dinamike pojavljanja potreb po novem znanju in spretnostih izrazito fenotipsko. Potrebe se pojavljajo kot odgovor na hitre, nepričakovane spremembe $v$ podjetjih, na domačem in svetovnih trgih, $v$ kraju in širši skupnosti. Številne potrebe po novem znanju in spretnostih zahtevajo hiter odgovor, pri čemer mora biti program izobraževanja ali usposabljanja čimbolj vpet v dejanske okolišcine, $v$ katerih so potrebe nastale. Zaposleni se praviloma izobražujejo z jasno predstavo o tem, kakšno znanje potrebujejo in kje ga bodo morali biti sposobni uporabiti: poslovno angleščino za pogovore s tujimi partnerji, nove računovodske predpise za obračunavanje plač ipd.

Zaposleni in podjetja potrebe po novem znanju različno rešujejo. Uspešnost njihovega iskanja rešitev je odvisna od številnih dejavnikov, od izobraževalne ponudbe do sposobnosti za izbiro najprimernejših poti in pridobitev izvajalcev za posamezne vrste izobraževanja.

Od zahtevnosti delovnega mesta, odgovornosti in kompleksnosti nalog je odvisno, koliko manjših in večjih učnih projektov izpelje vsak zaposleni. Allen Tough (1972) opredeljuje učni projekt kot »večji, zavesten napor za pridobitev določenega znanja in spretnosti«, pri čemer gre lahko za pridobitev novih vrst znanja, boljše razumevanje drugih, razvijanje novih spretnosti, spremembo lastnih navad ipd. Nekateri zaposleni se morajo vsak dan spopasti s številnimi problemi, ki

Za gospodarstvo je značilna čedalje večja individualizacija potreb. zahtevajo pridobitev pravih informacij in znanja, drugi se zaradi rutinskosti svojega dela z novimi izzivi skoraj ne srečujejo. Kako uspešen je posameznik pri iskanju informacij in njihovi izbiri, je odvisno od njegove razgledanosti in izobraženosti, sposobnosti za iskanje in uporabo informacij, iznajdljivosti, sposobnosti za komuniciranje, samozavesti, samopodobe in osebnostnih lastnostih. Zaposleni z višjo in visoko izobrazbo, ki živijo v okolju z razvito mrežo informacijsko-izobraževalne ponudbe in medijev, so navadno sposobni sami poiskati pot do potrebnega znanja in informacij, učenje ter izobraževanje pa sta za njih nekaj samoumevnega. Velik del njihovega učenja in samoizobraževanja zato že poteka »na daljavo«, prek različnih medijev in interneta, ne da bi temu pripisovali posebno pozornost.

Številnih potreb zaposlenih $v$ gospodarstvu ni mogoče reševati sproti, $\mathrm{z}$ individualnim iskanjem in pridobivanjem potrebnih informacij ter podatkov. Predvsem kadar gre za obsežnejše znanje na področjih, ki s posameznikovo poklicno usposobljenostjo ni neposredno povezano ali zadeva nove pristope in nove tehnologije, in kadar gre za razvijanje novih spretnosti, osebnostnih lastnosti, navad in sposobnosti, je treba za izobraževanje pripraviti poseben izobraževalni program. Da ta resnično doseže svoj namen, morajo biti vsebine in izvedba načrtovane glede na dejanske potrebe in okoliščine, $v$ katerih bodo določeno znanje, spretnosti ali sposobnosti potrebne. Za izobraževalne potrebe, ki se danes pojavljajo $\mathrm{v}$ gospodarstvu, je $\mathrm{z}$ vidika vrst in oblik izobraževalnih programov težko najti skupni imenovalec, dejstvo pa je, da je razvoj usmerjen $\mathrm{k}$ vse večji individualizaciji in da izobraževalni programi čedalje bolj nastajajo zaradi potreb določenega posameznika in specifičnih okoliščin, ki so z njim povezane (predznanje, razpoložljiv čas, ciljne potrebe ipd.), čeprav sama izvedba izobraževanja poteka v skupini. Izobraževanje mora dati konkreten odgovor na konkretno potrebo posameznega zaposlenega.

Vloga, ki jo ima pri tem lahko izobraževanje na daljavo, je povezana predvsem z vrstami vsebin in ciljno populacijo. Krajši ali daljši programi na daljavo so za zaposlene v podjetjih lahko velika prednost, saj jim omogočijo lažje organiziranje časa, ki ga bodo namenili študiju, pa tudi učinek takega učenja je zato lahko veliko večji, saj lahko posameznik štu- 
dira tako, kot mu ustreza, in se že pred konzultacijami ali morebitnim srečanjem z mentorjem seznani z vsebinami. Dejstvo je sicer, da je pri nas predstava o izobraževanju še vedno zelo povezana $\mathrm{z}$ delom $\mathrm{v}$ skupini ob navzočnosti predavatelja. Izobraževanje $v$ skupini ima nesporne prednosti in je pomembno za vse izobraževalne programe, pri katerih so poleg pridobivanja znanja pomembni razvijanje sposobnosti komuniciranja, strategij za skupinsko delo, reševanje problemov in iskanje rešitev na podlagi diskusije med udeleženci in $\mathrm{v}$ interakciji s predavateljem.

Vendar je zelo velik del izobraževalnih programov namenjen predvsem posredovanju različnih vrst podatkov, informacij, predpisov in dognanj. Za take vsebine je priprava programov za izobraževanje na daljavo vsekakor smiselna. Različne »faktografske« vsebine je mogoče posredovati prek medijev: kot pisno gradivo ali skripta, računalniške datoteke, včasih tudi z videokonferenčnimi povezavami. Priprava gradiva sicer zahteva določeno znanje in izkušnje, vendar ponuja po drugi strani sodobna tehnologija izredne tehnične možnosti za oblikovanje in posredovanje takih vsebin - z ustrezno računalniško opremo lahko mentor celo sam pripravi vsaj pisno gradivo, z nekaj več znanja pa tudi sam oblikuje CD-ROM ali spletno stran.

Pri iskanju najprimernejših rešitev za potrebe po izobraževanju, so podjetja in posamezniki seveda odvisni od ponudbe. Večja podjetja skušajo čim več potreb, povezanih s strokovnim izpopolnjevanjem zaposlenih, rešiti ob pomoči lastnih strokovnjakov. $\mathrm{V}$ teh primerih se morajo pobude za pripravo gradiva za samostojno izobraževanje razviti v podjetju. Pri zunanjih izvajalcih izobraževalnih programov pa je razvijanje izobraževalnih programov na daljavo prepuščeno izobraževalnim podjetjem samim. Tovrstna izobraževalna ponudba pri nas (še) ni znana in razširjena. To je povezano s tem, da izobraževanje na daljavo pri nas nima tradicije in da dejansko nimamo (dovolj) strokovnjakov, ki bi lahko svetovali pri pripravi programov za izobraževanje na daljavo. Rredka podjetja za izobraževalne storitve imajo zaposlene andragoge ali strokovnjake za razvijanje izobraževalnih programov za odrasle, zato je njihova izobraževalna ponudba omejena na organiziranje skupinskih oblik izobraževanja, predvsem seminarjev in tečajev, za katere najamejo predavatelja, ki je strokovnjak za določeno področje. Upamo, da bodo izkušnje tistih organizacij, ki se pri nas z izobraževanjem na daljavo že ukvarjajo, pa tudi razvejenost izobraževalne ponudbe na daljavo $\mathrm{v}$ tujini, pripomogle $\mathrm{k}$ večjemu interesu slovenskih izobraževalnih podjetij za razvijanje takih programov strokovnega izpopolnjevanja.

Izobraževanje na daljavo ima za slovensko gospodarstvo še eno pomembno vlogo, in sicer kot študij na daljavo v obliki krajših strokovnih ali daljših višješolskih programov. Poleg potrebe po pridobivanju strokovnega znanja je za slovensko gospodarstvo značilen tudi problem nizke izobrazbe zaposlenih. Pravilo, da je veriga trdna, kolikor je trden njen najšibkejši člen, se v gospodarstvu pogosto izkaže za kruto resničnost. Nenatančno delo šivilje $\mathrm{v}$ proizvodnji, neprimerno vedenje tajnice ali telefonista, neodgovoren odnos kurirja lahko naredijo več škode kot prizadevanje strokovnjakov in vodilnih delavcev. V interesu podjetij in gospodarstva je zato poleg strokovnega usposabljanja in izpopolnjevanja $\mathrm{z}$ vidika specifičnega znanja tudi dvigovanje splošnoizobrazbene ravni zaposlenih v podjetju in gospodarstvu. Klasični izredni študij, ki ga poznamo pri nas, temelji na posredovanju znanja na predavanjih, ki jih visoke šole organizirajo tudi trikrat na teden, to pa je za zaposlene veliko breme. V razvitih državah je taka oblika visokošolskega študija odraslih povsem preživeta in upravičeno smo lahko razočarani nad skoraj popolnim ignoriranjem, ki 
ga pristojni kažejo do razvijanja visokošolskega študija na daljavo.

\section{SKLEPNE MISLI}

Izobraževanje na daljavo ponuja slovenskemu gospodarstvu veliko možnosti, saj odpira sodobna tehnologija številne poti za posredovanje znanja, podatkov in informacij. Zaposleni $\mathrm{v}$ gospodarstvu so vse bolj razpeti med potrebami po stalnem izpopolnjevanju in izobraževanju na eni strani in pomanjkanjem časa na drugi strani, zato bi morale izobraževalne organizacije in podjetja predvsem na tistih področjih, kjer narava vsebin to omogoča, več

E-izobraževanje je učinkovit odgovor na izobraževalne potrebe ob pomanjkanju časa. pozornosti namenjati razvijanju programov za vodeno samoizobraževanje in izobraževanje na daljavo.

Priprava programa, ki se izvaja na daljavo, zahteva sicer bistveno drugačno zasnovo od seminarske ali tečajne oblike, saj je treba vnaprej pripraviti gradivo, s katerim posameznik predela določeno snov, vendar sodobna tehnologija ponuja tudi vse več tehničnih možnosti za pripravo kakovostnega gradiva. Za zaposlene je velika prednost take oblike izobraževanja $\mathrm{v}$ tem, da lahko določeno snov predelajo sami, tam in takrat, kjer in kadar jim druge obveznosti to omogočajo. Z mentorjem se lahko sreča ali poveže šele takrat, ko je snov že predelal, in je treba oceniti, ali je pridobljeno znanje sposoben uporabiti.

$\mathrm{Za}$ gospodarstvo pa so poleg krajših oblik strokovnega izobraževanja zelo pomembne tudi različne oblike strokovnega in visokošolskega študija na daljavo pri dvigovanju ravni splošne izobrazbe zaposlenih. 